\title{
8: $108579430-108330886$
}

National Cancer Institute

\section{Source}

National Cancer Institute. 8: 108579430-108330886. NCI Thesaurus. Code C41691.

Physical location of ANGPT1_Gene 